\title{
Absorption, Translocation, and Metabolism of Sethoxydim in Centipedegrass and Goosegrass
}

\author{
Lambert B. McCarty ${ }^{1}$ \\ Department of Environmental Horticulture, 1523 Fifield Hall, University of Florida, Gainesville, \\ FL 32611 \\ Jeffery M. Higgins ${ }^{2}$ \\ Department of Agronomy, Clemson University, Clemson, SC 29634-0375 \\ Frederick T. Corbin ${ }^{3}$ \\ Crop Science Department, North Carolina State University, Raleigh, NC 27695-7620 \\ Ted Whitwell ${ }^{3}$ \\ Horticulture Department, Clemson University, Clemson, SC 29634-0375 \\ Additional index words. selectivity, turfgrass, lawns, herbicide fate, thin-layer chromatography
}

\begin{abstract}
Absorption, translocation, and metabolism of foliar-applied ${ }^{14} \mathrm{C}$-labeled sethoxydim $\left({ }^{14} \mathrm{C}\right.$-sethoxydim) in sethoxydim-tolerant centipedegrass [Eremochloa ophiuroides (Munro) Hack.] and sethoxydim-sensitive goosegrass [Eleusine indica (L.) Gaertn.] were determined. The distribution of ${ }^{14} \mathrm{C}$ in treated leaves indicated that similar amounts $(\approx 3 \%)$ were found in the epicuticular wax fraction (chloroform wash) of both species after 6 hours. After 2 hours, $16 \%$ of the applied ${ }^{14} \mathrm{C}$-sethoxydim was absorbed in the treated leaf by centipedegrass, but only $2 \%$ was absorbed by goosegrass. After 2 hours, centipedegrass also readily translocated greater amounts of ${ }^{14} \mathrm{C}$ than goosegrass $(4.3 \%$ vs. $0.4 \%$ ). Six hours after treatment, however, no differences were found in amounts absorbed by the treated leaf and translocated to apical and basal leaves. Because sethoxydim-tolerant centipedegrass absorbed and translocated similar amounts of ${ }^{14} \mathrm{C}$ compared to the sethoxydim-sensitive goosegrass, these two mechanisms do not appear to be a means of tolerance. The major difference found between the two species was in the metabolism of sethoxydim. After 6 hours, $81 \%$ to $98 \%$ of the ${ }^{14} \mathrm{C}$ in goosegrass extracts remained as ${ }^{14} \mathrm{C}$-sethoxydim. In contrast, only $1 \%$ of the ${ }^{14} \mathrm{C}$ found in apical leaves, basal leaves, and roots of centipedegrass was identified as ${ }^{14} \mathrm{C}$-sethoxydim. These data indicated that differences in tolerance to sethoxydim between these two species were based on metabolism. Chemical name used: 2-[1-(ethoxyimino) butyl]-5-[2-(ethylthio)propyl]-3-hydroxy-2 -cyclohexen-1-one (sethoxydim).
\end{abstract}

Sethoxydim is a foliarly applied, systemic herbicide that selectively controls monocotyledonous weed species (Chernicky et al., 1984; Hosaka et al., 1984). Tolerance to sethoxydim has been reported for some monocotyledonous turf species (Butler and Appleby, 1986; Hosaka et al., 1984; McCarty et al., 1986). Red fescue (Festuca rubra) and centipedegrass are tolerant to sethoxydim at amounts as high as $1.12 \mathrm{~kg} \cdot \mathrm{ha}^{-1}$ (Anderson and Coats, 1985; Butler and Appleby, 1986; Hosaka et al., 1984; McCarty et al. 1986; Wells and Constantin, 1985). Goosegrass control (> 90\%) by sethoxydim at $0.44 \mathrm{~kg} \cdot \mathrm{ha}^{-1}$ has been observed (Chernicky et al., 1984). A question is therefore raised as to the basis of herbicide selectivity between the monocotyledons centipedegrass and goosegrass.

Penetration and translocation of ${ }^{14} \mathrm{C}$-sethoxydim have been evaluated in several crop species (Campbell and Penner, 1980; Hosaka and Takagi, 1987; Nalewaja and Skrzypczark, 1986; Rhodes and Coble, 1984; Swisher and Corbin, 1982; Wills, 1984). Translocation of ${ }^{14} \mathrm{C}$ was similar in most species foat (Avena sativa L.), sunflower (Helianthus annuus L.), linseed (Linum usitatissimum L.), soybean [Glycine max (L.) Merr.], johnsongrass [Sorghum halepense (L.) Pers.], pea (Pisum sativum L.), and goosegrass $\}$ with accumulation in regions of high

Received for publication 7 July 1989. Technical contribution no. 3029 of the South Carolina Agricultural Experimental Station, Clemson Univ. The ${ }^{14} \mathrm{C}-$ sethoxydim was a gift from the BASF-Wyandotte Corp. We thank Bonnie Sheldon for her excellent technical assistance. The cost of publishing this paper was defrayed in part by the payment of page charges. Under postal regulations, this paper therefore must be hereby marked advertisement solely to indicate this fact.

'Assistant Professor.

${ }^{2}$ Former Graduate Associate.

${ }^{3}$ Professor metabolic activity. Rhodes and Coble (1984) found ${ }^{14} \mathrm{C}$-sethoxydim translocation to be both acropetal and basipetal.

Campbell and Penner (1985) examined the extent of sethoxydim metabolism in monocotyledonous and dicotyledonous plants. ${ }^{14} \mathrm{C}$-sethoxydim was rapidly metabolized by quackgrass [Agropyron repens (L.) Beauv.], barnyardgrass [Echinochloa crusgalli (L.) Beauv.], alfalfa [Medicago sativa L. 'Saranac'], and navy bean [Phaseolus vulgaris L. 'Seafarer']. Ninety-eight percent of sethoxydim was metabolized after $24 \mathrm{hr}$ in all species. Two metabolizes, previously shown to be phytotoxic to barnyardgrass, contained the majority of ${ }^{14} \mathrm{C} 24 \mathrm{hr}$ after application (Campbell and Penner, 1980). They concluded that differences in metabolism of sethoxydim in treated leaves could not account for selectivity between susceptible monocots and tolerant dicotyledonous crop plants.

Sethoxydim's mode of action is reported to involve plant membrane lipid alteration or modification (Hatzios, 1982). Burton et al. (1988), however, suggested that sethoxydim prevents fatty acid biosynthesis by inhibiting acetyl-coenzyme A carboxylase.

We have observed that centipedegrass is tolerant to sethoxydim, but information is lacking on the basis of selectivity between centipedegrass and goosegrass (McCarty et al., 1986). Therefore, research was conducted to examine absorption, translocation, and metabolism of ${ }^{14} \mathrm{C}$-sethoxydim in a sethoxydim-tolerant turfgrass species (centipedegrass) and a sethoxydim-sensitive weed species (goosegrass).

\section{Materials and Methods}

Centipedegrass was established from 2-cm-long stolons and goosegrass from seeds. Both grasses were placed in 1-liter styr- 
ofoam cups containing a 1 peat : 1 pearlite (v/v) amended potting medium. Grass plants were thinned to one plant per pot 3 weeks after establishment. Pots were watered once daily and fertilizer solution $(15 \mathrm{~N}-16 \mathrm{P}-17 \mathrm{~K})$ was added every other week until treatment. Plants were grown in a controlled environment with days/nights at 30/24C and 16-hr photoperiods. Light intensity was $400 \mu \mathrm{mol} \cdot \mathrm{s}^{-1} \cdot \mathrm{m}^{2}$,and relative humidity ranged from $60 \%$ to $75 \%$.

Uniformly ring-labeled ${ }^{14} \mathrm{C}$-sethoxydim $(0.5 \mu \mathrm{Ci} / \mathrm{ml} ; 1 \mathrm{Ci}=$ $37 \mathrm{GBq}$ ) was applied with a micropipette to the adaxial side of the second leaf of four-leaf-stage centipedegrass and third leaf of six-leaf-stage goosegrass. Radiolabeled sethoxydim (specific activity $13.06 \mu \mathrm{Ci} / \mu \mathrm{mol}$ ) was applied in a total volume of 10 $\mu$ l. Oxysorbic [20 polyoxyethylene sorbitan monolaurate (POE)] surfactant was added at $0.1 \%(\mathrm{v} / \mathrm{v})$ to the stock solution. Two and $6 \mathrm{hr}$ following application, plants were harvested and roots washed with water to remove potting medium. Each plant was sectioned into four parts: treated leaf, shoots above treated leaf (apical leaves), shoots below treated leaf (basal leaves), and roots.

Absorption, penetration, and metabolism. Each treated leaf was placed in a glass bottle containing $20 \mathrm{ml}$ of distilled $\mathrm{H}_{2} \mathrm{O}$ and shaken for $1 \mathrm{~min}$. An additional $10 \mathrm{ml}$ of distilled $\mathrm{H}_{2} \mathrm{O}$ was used to wash the leaves upon removal from the bottle. A 2-ml sample was then combined with ${ }^{14} \mathrm{CO}_{2}$-labeled absorbent cocktail solution $\left({ }^{14} \mathrm{CO}_{2} \mathrm{UNT}-\mathrm{SORB}\right.$, Research Products Intl., Mt. Prospect, Ill.) and assayed by liquid scintillation spectrometry (Packard Tri-Carb Model 3255, Packard Instrument, Downers Grove, Ill.) to quantiate unabsorbed sethoxydim. The treated leaf was then placed in a glass bottle containing $20 \mathrm{ml}$ of chloroform and shaken for 1 min to extract any herbicide present in the leaf epicuticular wax. An additional $10 \mathrm{ml}$ of chloroform was used to rinse the leaf upon removal. Chloroform extracts were evaporated to dryness in vacuo at $37 \mathrm{C}$. Methanol $(30 \mathrm{ml})$ was added to the crystalline extract and a 2-ml sample taken for counting in liquid scintillation spectrometry. Quench corrections were obtained by the external standard method. Treated leaf and other sectioned plant parts were placed in separate glass bottles with $30 \mathrm{ml}$ of methanol and homogenized for $1 \mathrm{~min}$ with an electric homogenizer. Bottles were washed with $5 \mathrm{ml}$ of methanol and samples were homogenized for an additional $1 \mathrm{~min}$. Samples were filtered through two layers of filter paper under vacuum and additional methanol added to obtain a total filtrate volume of $50 \mathrm{ml}$. A 2-ml sample was taken from filtrates and quantified by liquid scintillation spectrometry. Filtrates were then evaporated to dryness in vacuo at $37 \mathrm{C}$ to concentrate radioactive forms. Methanol and chloroform, $0.5 \mathrm{ml}$ of each, were added to the dry methanol extract precipitates to redissolve the radioactive forms in preparation for metabolize separation by thin-layer chromatography (TLC).

Silica gel TLC analytical plates $(250 \mu \mathrm{m})$ (Whatman K61 Silica gel TLC plates) were used to separate ${ }^{14} \mathrm{C}$ compounds in extracts. A 100- $\mu$ l sample from each methanol extract was spotted $2 \mathrm{~cm}$ from the bottom of the TLC plates. Each plate was spotted with analytical grade sethoxydim for ultraviolet location of parent herbicide. TLC plates were developed in a 5 hexane : 1 acetone $(\mathrm{v} / \mathrm{v})$ solvent system to a $15-\mathrm{cm}$ solvent front. A second solvent system, 65 chloroform : 25 methanol : $4 \mathrm{H}_{2} \mathrm{O}$ (by volume), was used independently from the hexane : acetone system to separate potential polar metabolizes from the origin.

Radioactive peaks and $R_{f}$ values were located by scanning TLC plates with a radiochromatogram scanner (Bioscan System 400 Imaging Scanner, Washington, D.C.) and quantified by liquid scintillation spectrometry.

Data analysis. Treatments were arranged in a randomized complete block design with three replications. The experiment was repeated and data presented as an average over experiments. Results were adjusted to a common recovery rate of $100 \%$ for ease of presentation. Data were subjected to analysis of variance and plant part means were compared between species by least significant differences (LSD) at the 5\% level.

\section{Results and Discussion}

Absorption and translocation. The bulk of ${ }^{14} \mathrm{C}$-sethoxydim remained on leaf surfaces of both grass species 2 and $6 \mathrm{hr}$ after application (Table 1). However, the initial absorption of the ${ }^{14} \mathrm{C}$ sethoxydim in the treated leaf differed between centipedegrass and goosegrass (Table 1). Sixteen percent of applied radioactivity was recovered at $2 \mathrm{hr}$ in the centipedegrass treated leaf, but only one-eighth as much in goosegrass, suggesting that less absorption occurred initially in goosegrass than in centipedegrass. After $6 \mathrm{hr}$, differences in absorption between species were not evident, indicating that, over time, differential absorption of sethoxydim does not occur in these two grass species. Our data are in agreement with the work of previous researchers, who reported large amounts of sethoxydim on leaf surfaces after $6 \mathrm{hr}$ (Rhodes and Coble, 1984).

Amounts of ${ }^{14} \mathrm{C}$-sethoxydim translocated averaged $\approx 1.5 \%$ in centipedegrass apical leaves, basal leaves, and roots $2 \mathrm{hr}$ after treatment, but $0.2 \%$ or less in goosegrass (Table 1 ). The extent of translocation $6 \mathrm{hr}$ after treatment was similar for both species throughout all parts. Apparently, centipedegrass initially absorbed and translocated ${ }^{14} \mathrm{C}$-sethoxydim faster than goosegrass, but, after $6 \mathrm{hr}$, similar amounts were found in both grass species.

Metabolism. Three major ${ }^{14} \mathrm{C}$ peaks were located by ultra-

Table 1. Distribution of ${ }^{14} \mathrm{C}$ in leaf washes, centipedegrass, and in goosegrass when analyzed 2 or 6 hr after foliar application of ${ }^{14} \mathrm{C}$ sethoxydim².

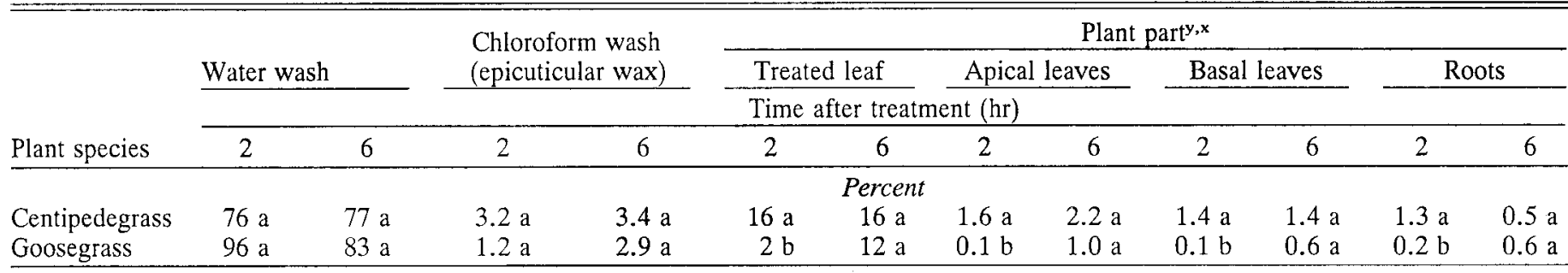

"Percentage of ${ }^{14} \mathrm{C}$ based on $100 \%$ recovery.

${ }^{y}$ Data are the means of six observations.

xValues followed by the same letter within a plant part over the same time intervals are not significantly different between species at $P=0.05$. 326 
Table 2. Percentage of ${ }^{14} \mathrm{C}$-sethoxydim and two of its metabolizes in centipedegrass and goosegrass 2 and $6 \mathrm{hr}$ after foliar applications.

\begin{tabular}{|c|c|c|c|c|c|c|c|c|c|}
\hline \multirow[b]{4}{*}{ Plant species } & \multirow{4}{*}{ TLC position $^{\mathbf{x}}$} & \multicolumn{8}{|c|}{ Plant party } \\
\hline & & \multirow{2}{*}{\multicolumn{2}{|c|}{ Treated lèaf }} & \multirow{2}{*}{\multicolumn{2}{|c|}{$\frac{\text { Apical leaves }}{\text { Time after }}$}} & \multirow{2}{*}{\multicolumn{2}{|c|}{$\frac{\text { Basal leaves }}{\text { atment (hr) }}$}} & \multicolumn{2}{|c|}{ Roots } \\
\hline & & & & & & & & & \\
\hline & & 2 & 6 & 2 & 6 & 2 & 6 & 2 & 6 \\
\hline & & & & & $\mathrm{Per}$ & ent & & & \\
\hline \multirow[t]{3}{*}{ Centipedegrass } & Metabolite A & 19 & 13 & 98 & 98 & 98 & 98 & 98 & 98 \\
\hline & Metabolite B & 7 & 4 & 1 & 1 & 1 & 1 & 1 & 1 \\
\hline & Parent sethoxydim & 74 & 83 & 1 & 1 & 1 & 1 & 1 & 1 \\
\hline \multirow[t]{3}{*}{ Goosegrass } & Metabolite A & 17 & 1 & 1 & 5 & 1 & 6 & 1 & 7 \\
\hline & Metabolite B & 6 & 9 & 1 & 14 & 1 & 14 & 1 & 3 \\
\hline & Parent sethoxydim & 77 & 90 & 98 & 81 & 98 & 80 & 98 & 90 \\
\hline
\end{tabular}

${ }^{2}$ Percentage of ${ }^{14} \mathrm{C}$ based on $100 \%$ recovery from TLC plate.

${ }^{y}$ Data are the means of six observations.

${ }^{x} R_{f}$ values for $\mathrm{A}, \mathrm{B}$, and parent sethoxydim peaks were $0,0.57$, and 0.84 , respectively. Obtained by TLC in 65 chloroform : 25 methanol : 4 water (by volume).

violet light $(254 \mathrm{~nm})$ and by radiochromatogram scanning of TLC separations (Table 2). These peaks had $R_{f}$ values of 0 (origin), 0.57, and 0.84 and are designated as peaks A, B, and parent sethoxydim, respectively. Peak A remained at or near the origin and is believed to be a polar conjugate of sethoxydim. Peak B is an unknown metabolize, while peak C co-chromatographed with parent sethoxydim.

The proportion of parent sethoxydim and its metabolizes changed over time, with differences between centipedegrass and goosegrass being evident (Table 2). After $6 \mathrm{hr}, 83 \%$ of the ${ }^{14} \mathrm{C}$ in centipedegrass treated leaves was sethoxydim. However, in apical leaves, basal leaves, and roots only trace amounts (1\%) of sethoxydim were observed. This result suggests that centipedegrass at least partially metabolizes or transforms the herbicide into nonphytotoxic forms(s). In contrast, after $6 \mathrm{hr}, 81 \%$ to $98 \%$ of the ${ }^{14} \mathrm{C}$ remained as unaltered sethoxydim in goosegrass apical leaves, basal leaves, and roots. Thus, tolerance of centipedegrass and sensitivity of goosegrass to sethoxydim can be explained in part by differences in metabolism of the herbicide between the two species.

\section{Literature Cited}

Anderson, D.H. and G.E. Coats. 1985. Evaluation of sulfonated urea herbicides for turfgrasses. South. Weed Sci. Soc. Proc. 38:98. (Abstr.)

Burton, J.D., J.W. Gronwald, D.A. Somers, B.G. Gengenbach, and D.L. Wyse. 1988. Inhibition of acetyl-coenzyme A carboxylase by sethoxydim and haloxyfop. Weed Sci. Soc. Amer. 28:178. (Abstr.)

Butler, J.H.B. and A.P. Appleby. 1986. Tolerance of red fescue (Festuca rubra) and bentgrass (Agrostis spp.) to sethoxydim. Weed Sci. 34:457-461.

Campbell, J.R. and D. Penner. 1985. Sethoxydim metabolism in monocotyledonous and dicotyledonous plants. Weed Sci. 33:771-773.
Campbell, J.R. and D. Penner. 1981. Absorption and translocation of BAS 9052 OH 2-[1-(ethoxyimino)-butyl]-5-[2-ethylthio)priopyl]-3hydroxy-2-cyclochexen-1-one. Weed Sci. Soc. Amer. Proc. 21:108. (Abstr.)

Campbell, J.R. and D. Penner. 1980. Nonbiological transformation of BAS-9052-OH. North Central Weed Control Conf. Proc. 35:17. (Abstr.)

Chernicky, J.P., B.J. Gossett, and T.R. Murphy. 1984. Factors influencing control of annual grasses with sethoxydim and RO-13-8895. Weed Sci, 32:174-177.

Hatzios, K.K. 1982. Effects of sethoxydim on the metabolism of isolated leaf cells of soybeans [Glycine $\max (\mathrm{L}$.) Merr.]. Plant Cell Rpts. 1:87-90.

Hosaka, H., H. Inaba, and H. Ishikawa. 1984. Response of monocotyledons to BAS $9052 \mathrm{OH}$. Weed Sci. 32:28-32.

Hosaka, H. and M. Takagi. 1987. Selectivity of mechanisms of sethoxydim absorption into tissues of corn (Zea mays) and pea (Pisum sativum). Weed Sci. 35:619-622.

McCarty, L.B., J.M. Higgins, L.C. Miller, and T. Whitwell. 1986. Centipedegrass tolerance to postemergence grass herbicides. HortScience 21(6):1405-1407.

Nalewaja, J.D. and G.A. Skrzypczak. 1986. Absorption and translocation of sethoxydim with additives. Weed Sci. 34:657-663.

Rhodes, G.N., Jr., and H.D. Coble. 1984. Influence of bentazon on absorption and translocation of sethoxydim in goosegrass. Weed Sci. 32:595-597.

Swisher, B. and F.T. Corbin. 1982. Behavior of BAS-9052 in soybean (Glycine max) and johnsongrass (Sorghum halepense) plant and cell cultures. Weed Sci. 30:640-650.

Wells, D.W. and R.J. Constantin. 1985. Response of centipede to selected herbicide treatments. South. Weed Sci. Soc. Proc. 38:99. (Abstr.)

Wills, G.D. 1984. Toxicity and translocation of sethoxydim in bermudagrass (Cynodon dactylon) as affected by environment. Weed Sci. 32:20-24. 